\title{
CRACOW \\ INDOLOGICAL \\ STUDIES
}

Crossing over "on the Birds' Wings":

South Asian Literature in Local and Global Contexts

VOL. XVII Edited by Tatiana Dubyanskaya

KRAKÓW 2015 JAGIELLONIAN UNIVERSITY INSTITUTE OF ORIENTALSTUDIES

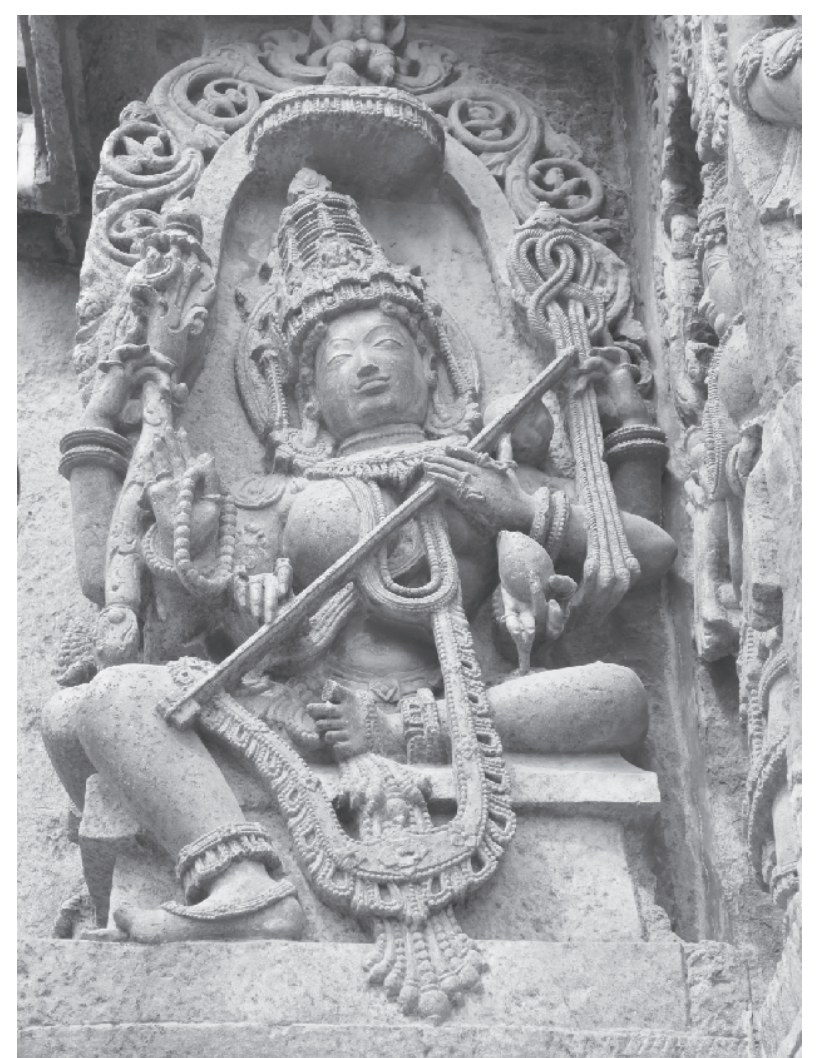


Technical Editor:

Tomasz Winiarski

(C) Institute of Oriental Studies, Jagiellonian University, Cracow and the Authors

Department of Languages and Cultures of India and South Asia, Jagiellonian University

ul. Podwale 7, 31-118 Kraków

cracow_indological_studies@uj.edu.pl

Information for the

Authors:http://www.indologia.io.filg.uj.edu.pl/badania/

cracow-indological-studies

http://www.akademicka.pl/cis

The volume was published thanks to the financial support of: Ministry of Science and Higher Education

Published in the e-book form plus 200 paper copies. The primary version of the journal is the electronic format.

ISSN 1732-0917

eISSN 2449-8696

PUBLISHER:

Fundacja Centrum Dokumentacji Czynu Niepodległościowego

Al. Mickiewicza 22, 30-059 Kraków e-mail: sowiniec@gmail.com

\section{DISTRIBUTION:}

„Księgarnia Akademicka” sp. z o.o.

ul. św. Anny 6, 31-008 Kraków

e-mail: akademicka@akademicka.pl

www.akademicka.pl 


\section{Cracow Indological Studies}

vol. XVII (2015)

10.12797/CIS.17.2015.17.04

\section{Nicola Pozza \\ Nicola.Pozza@unil.ch \\ (University of Lausanne, Switzerland)}

\section{Wandering Writers in the Himalaya: Contesting Narratives and Renunciation in Modern Hindi Literature}

SUMMARY: The Himalayan setting-especially present-day Himachal Pradesh and Uttarakhand - has fascinated many a writer in India. Journeys, wanderings, and sojourns in the Himalaya by Hindi authors have resulted in many travelogues, as well as in some emblematic short stories of modern Hindi literature. If the environment of the Himalaya and its hill stations has inspired the plot of several fictional writings, the description of the life and traditions of its inhabitants has not been the main focus of these stories. Rather, the Himalayan setting has primarily been used as a narrative device to explore and contest the relationship between the mountain world and the intrusive presence of the external world (primarily British colonialism, but also patriarchal Hindu society). Moreover, and despite the anti-conformist approach of the writers selected for this paper (Agyeya, Mohan Rakesh, Nirmal Verma and Krishna Sobti), what mainly emerges from an analysis of their stories is that the Himalayan setting, no matter the way it is described, remains first and foremost a lasting topos for renunciation and liberation.

KEYWORDS: Himalaya, Hindi, fiction, wandering, colonialism, modernity, renunciation, Agyeya, Nirmal Verma, Mohan Rakesh, Krishna Sobti.

\section{Introduction: Himalaya at a glance}

The Himalaya has been a place of fascination for non-residents since time immemorial and has attracted travellers, monks and pilgrims and itinerant merchants from all over Asia and Europe. From the fourth century onwards, its hard-to-access passes and valleys were, for Chinese pilgrims such as Faxian (337-c. 422), Xuanzang (602-664) or Yijing (635-713), unavoidable stages on the road to the active 
religious centres of the subcontinent, such as Nalanda. Later on, from the $17^{\text {th }}$ century onwards, this part of India has also fascinated European travellers (Teltscher 2002: 191-93). Around 1810, the beauty of its landscapes and the rich mythology that was associated with its inhabitants became the focus of interest and fascination of British scholars and administrators:

For over twenty years thereafter, the Asiatick Researches published article after article describing travelers' attempts to trace the course of India's fabled rivers to their sources or to ascend its mountain ranges to survey vistas previously unattained by a European. These narratives are the colonial administration's answer to the Romantic landscapes rendered by such British artists as J.M.W. Turner and Joseph Wright. On a literary level, they consistently proclaimed the power of the landscape to elicit particular emotional reactions, its alluring danger, and its encouragement to the attainment of a religious vision. (Pennington 2005: 133)

Coupled with "cartographic and strategic" interests and the valorisation of heroic journeys to "unknown" places in the mind of the British, the hilly valleys also held appeal because of their rather pleasant climate. In contrast to the plains, which in the $19^{\text {th }}$ century were seen more and more as "a stark, heat-shimmering, monotonously unvarying landscape, teeming with millions of idol-worshipping, disease-ridden people" (Kennedy 1996: 61), the hills became the new centre of attraction, either for their sanatoriums and touristic stations or for their new strategic role, be it as the summer capital of the British Raj in the case of Shimla (with official recognition in 1864), or as the seasonal headquarters of some of the provincial governments in Darjeeling, Shillong, and Nainital (ibid.: 4). After many environmental transformations (first, a radical deforestation and then its reforestation, but also the plantation of orchards), ${ }^{1}$ the Indian hills ${ }^{2}$ became a kind of "Eden" for the British (ibid.: 62). This metaphor

1 "It has been claimed that the first English apple tree to be transplanted into Indian soil was nurtured in Mussoorie" (ibid.: 47), around 1838.

2 Actually mountains, but the British preferred to minimize their size and called them "hills" in order to scale back "the overwhelming force of the landscape" (ibid.). 
can also be applied to the way the colonists shaped the ethnographic image of the indigenous:

The recurrent emphasis given to the gulf between the hills and the plains was essential to the ethnographic image of the peoples who inhabited the hills. [...] Boundaries were drawn that assured the officials and others who patronized the hill stations that these enclaves and their aboriginals were a world apart from the harrying subcontinent with its confusing, contentious, and subversive hordes. [...] The purpose of these tropes [i.e. moral innocence of the noble savage, rustic simplicity of the pastoral life, primitive egalitarianism of the peasant village] was clear - to fashion an image of these peoples as the noble guardians of Edenic sanctuaries. (ibid.: 87)

This image of the hill populations and its tropes has had a lasting effect on the mind not only of the European but also of the Indian, as will be seen in some of the short stories analysed below. The opposition between the plain and the hills has then been extended to an opposition between the "artificial" life of the modern urban centres and the "purity" of the Indian countryside and mountains in the 1910s-1940s. This antagonistic representation was best developed by M. K. Gandhi, whose idealistic notion of the village was itself indebted to British romanticism through Theosophy. In Gandhi's belief, India was to become a genuinely free country only if its socio-political structure and ideals were based on the model of the village:

I am convinced that if India is to attain true freedom and through India the world also, then sooner or later the fact must be recognised that people will have to live in villages, not in towns, in huts, not in palaces. Crores of people will never be able to live at peace with each other in towns and palaces. $[\ldots]$ We can realise truth and non-violence only in the simplicity of village life. ${ }^{3}$

This part of the country and its projected way of life has remained an object of fascination, and covetousness, in the mind of outsiders, be it from the point of view of culture, religion or nationalism.

3 Gandhi 1997: 150 ("Letter to Nehru, Oct. 5, 1945"). 
Since India gained its independence in 1947, the integrity and unity of the country has constantly been one of her most important issues. The disputed borders between India and Pakistan as well as China are the result of unresolved territorial claims and conflicts dating back to the $19^{\text {th }}$ century, and are at the origin of the 1962 Sino-Indian War and the 1947 and 1965 Indo-Pakistani Wars. Claims of territories by the surrounding countries and claims of autonomy by local populations and provinces have always been considered by the central government as an attack on the whole that constitutes the country. Sustaining this idea that India forms an undividable unit is the well-known leitmotiv of "unity in diversity", implying that behind the effective variety of cultures, languages and religions that form the nation, lies an unity, an "Indian essence" that links every single part of the nation and that cannot in any way be broken without causing the end of that entity that is India. ${ }^{4}$

One of the main regions that has been at the centre of this attention and that has epitomized this idea of cultural diversity seen as eminently important to the constitution of the identity of India is, precisely, the Himalaya. ${ }^{5}$ The will to integrate its populations and cultures into the "patchwork" that constitutes India is explicitly present in the position of both India's first Prime Minister Jawaharlal Nehru and his daughter, Indira Gandhi, third Prime Minister of the country. Daniela Berti (2009a: 10) explains how Nehru made use of the various folkloric dances from the Himalaya by inserting them into military

4 Jawaharlal Nehru was very clear with regard to the question of the integrity of the nation, especially during the 1950s, at the peak of the demands for the reorganisation of the States on a linguistic basis; see Brass 1990: 149ff.

5 It must be added that the Himalaya is also at the centre of attention in respect to economical and environmental issues through the question of hydroelectric resources and the construction of dams; this aspect will, however, not be dealt with here, as it does not intervene in the literary texts used in this paper. 
parades in Delhi, like during the Republic Day, in order to integrate removed areas into national unity:

In the Nehruvian model, folkloric and tribal cultures are taken as symbols of an "authentically Indian" past, whose diversity serves a political agenda based on national unity conceived as secular. (My translation)

The forced link made between the Indian past and local folklore was a way for the central authorities to reclaim territories that had fallen into foreign hands by minimizing, if not ignoring, the latter's enduring presence and impact on the local populations. Bishnu Dey thus claims in 1955 in an editorial entitled "The Future of our Folk Art" that the impact of the British government was unable to completely destroy the life, culture and art of the villagers (quoted in ibid:: 5). Berti summarizes the position of Dey's editorial, which corresponds also to the discourse of official booklets distributed during the Republic Day thirty years later:

Indian villages are seen as ideal and harmonious societies, "cradles" of an artistic sense that is conceived as "authentically Indian" because it has been unaffected by western colonization, and thus can be used in building a "truly" national culture". (Ibid.: 4)

In these two short quotations, Berti draws our attention to (at least) two aspects that have framed outsiders' (i.e. non-Himalayan) conceptions on these hilly regions and their inhabitants. First, these people are seen as living witnesses of the oldest Hindu civilization and need, therefore, to be treated with care, like old and precious pieces of antiquity or jewels. Secondly, if these populations and their art are considered as "authentic", it is because they have so far been spared by the "destructive" impact of western civilization. Of course, these "official" interpretations of the past clearly contradict both historical facts (see Kennedy 1996) and literary "testimonies" (see short stories below).

The above-mentioned leitmotiv of the integration of specific "folk" cultures into the unity that is India has, however, not been limited to the secularist position of Nehru and Indira Gandhi. 
Hindu nationalist leaders too - although the axioms of their approach is completely different from Nehru and Gandhi-have tended to incorporate and assimilate the specificities of these cultures under a unique banner, in this case the saffron banner of the Hinduisation of the country. In order to incorporate the various cultures of the Himalaya into a pan-Indian Hindu identity, their aim is to show — or even to "prove" with the help of recognized scientific methods (archaeology, etc.) the Aryan and Vedic origin of these peoples and their gods and goddesses (Berti 2009a: 15, 17). Here, "regional and tribal differences, far from being idealized as the trace of an 'authentically Indian' past (in the Nehruvian way), will instead be considered screens beyond which one must go back to uncover the 'Aryan' past" (ibid.: 12).

Thus, in the $20^{\text {th }}$ century, the Himalaya and its inhabitants became, as never before, not only the focus of attention of the new politics and their representations of the country, but also of Indian tourism and travel writing. ${ }^{6}$ With this context in mind, it would be interesting to look at the literary field and see how Hindi writers have represented the Himalaya in their works and how they have explored the loci of power with regard to the hills versus plains relationship. For that purpose, the following questions will guide the analysis of the fictional texts presented in the next part of this contribution? ${ }^{7}$. How do

${ }^{6}$ On this aspect, see Chandra 2007. Travel discourse on the Himalaya was closely linked to the nationalist agenda: "The new travel discourse that was emerging in the first quarter of the $20^{\text {th }}$ century through the children's journal in Hindi was a direct outcome of nationalist pedagogy - to make disciplined tourists, to orient them towards a love of the country and the rural in tandem with a nationalist reformist agenda. This nationalist project was invariably caught up in the tension between seeking modernity on the one hand, and producing its critique on the other." (ibid.: 296) Writing about one's travel into the hills was also a way to stress one's class and "a means to register the fact that one had arrived" (ibid.: 314 ), partly in response to a "huge complex" towards the British (ibid.: 316).

7 Given the number, and the length, of the short stories retained for this contribution, a close and complete analysis of the texts is not possible here. 
the writers deal with the nationalist notion of Himalayan populations being the inheritors and living witnesses of the ancient and authentic Hindu civilization? How do they represent the specificity of the hill cultures? And how do they depict and "stage" the contact, or its absence, between these populations and the outsiders, especially westerners? It will appear from the readings of the short stories selected for this study that if Agyeya addresses to some extent these issues in the preIndependence period, the authors writing after 1947 (Mohan Rakesh, Nirmal Verma and Krishna Sobti in this paper) are rather evasive on the same topics. However, as it will be seen in the conclusion, there is another topic - a trope one could say - that constantly emerges from these texts: the Himalaya seen first and foremost as a lasting, although changing, topos for renunciation and liberation.

\section{Analysis of a selection of Hindi short stories focused on the Himalaya}

The short stories selected for this paper have in common, firstly, the fact that they are all set in the Himalaya, from Manali in the Kullu valley to present-day Meghalaya, via Mussoorie and Nainital (the name of the places mentioned in the stories are shown in Figure 1 below, except for the story set in Meghalaya). Secondly, the stories all belong to authors who played a pioneering role in the development of modern Hindi literature, especially in its experimental and modernist sensibilities. These writers all interrogated the dominant social norms and values of their time, and valued style and language as much as the message they wanted to convey. ${ }^{8}$ The selected stories cover two distinct

Only the most important aspects for the questions raised here are developed in the next part of the paper.

8 Of course, other authors too have written on the Himalaya and could have been of interest to this research. It goes without saying that it would have gone far beyond the scope of this contribution to include them all, not to speak of the authors who do not directly correspond to the criteria set out here. One can especially think of Yashpal (1903-1976), who notoriously 
periods: the first group includes four stories written before the Independence by Agyeya. The second group includes three illustrative stories of the postcolonial period, more or less closely linked to the nai kahānī (New Story) movement, by Nirmal Verma, Mohan Rakesh and Krishna Sobti. If each group would be interesting to analyse in itself, a selection and comparison of stories belonging to two distinct periods is all the more heuristically useful in regard to some of the evolutions and changes that have taken place ivn Hindi literature with regard to the representation of the Himalaya as a narrative device. ${ }^{9}$

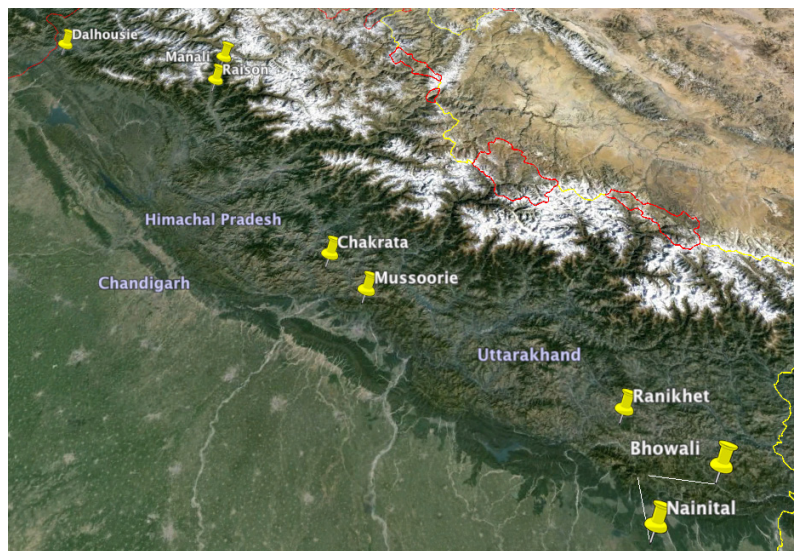

Figure 1.

wrote many stories set in the Himalayan background (for instance, "Tūfān kā daityă", "Śikāyat" or "Puruṣ bhagvān"), but whose literary sensibility significantly departed from the authors selected here. Nevertheless, if the description of local cultures is sometimes more developed in Yashpal's stories (like in "Tūfān kā daityă") than in Agyeya's, here too the life and customs of the Himalayan communities are never the main topic of his short stories and, as with the works used for this paper, the Himalayan setting is first and foremost a narrative device for exposing the author's critical views, dominated by Marxism, on the conservative and unegalitarian Hindu society as he saw it.

9 It must be noted right away that this comparison is only meant as a contrastive device allowing for some historical depth (to be refined and expanded by further research), and does not aim at providing an exhaustive picture of Hindi literature on the topic. 


\section{First period: short stories by Agyeya, pre-1947}

Saccidanand Hiranand Vatsyayan 'Agyeya' (1911-1987) was one of the most important writers of modern Hindi literature and is still highly praised in India today. Although his fame has not crossed the borders of his country, his influence on modern Hindi and Indian literature at large remains uncontested. ${ }^{10}$ Even if his criticism against his own Brahmanic social milieu has been constant, in parallel with a deep affinity with western cultures and literatures, Agyeya, nevertheless, made constant use of references from the Sanskrit tradition.

Among the short stories Agyeya wrote before the Independence, four are of major interest for our present purposes, as they provide very rich information on the way the author perceived the relation between the colonial power and the dominating Indian society on the one hand, and the Himalayan population and its environment on the other. These are "Pahāṛ̂i jīvan" ("Mountain Life", written in 1934), "Seb aur dev" ("Apples and Gods", 1937), "Bandom kā khudā, khudā ke bande" ("The God of Servants, the Servants of God", 1941), and "Hîlì-bon kì battakhem" ("Hili-Bon's Geese", 1947). Their common feature is that all four deal with an intellectual city-dweller - or a captain of the army in the fourth text-who wants to enjoy some rest and peaceful walking in the hills, away from the turmoil of the city (or the duties of the army). The city, and the masculinised world of the army, symbolizes the damage and negative influence of modern civilization on the local cultures of the Himalaya. As we have seen in the previous part, this opposition between the "artificial" life of the cities and the "purity" of the Indian countryside and mountains, which is at the origin of the characters' trip to the hills, represents a trope during this period. "Pahāṛi jīvan" can be read as a programmatic story, containing most of

10 Parts of the following paragraphs are taken from my article "Scope and Limits of 'Inclusivism' in Modern South Asia: Questioning Tagore's and Agyeya's 'Universalism"', to be published in the next issue of Politeja: The Journal of the Faculty of International and Political Studies of the Jagiellonian University in Krakow, edited by Renata Czekalska \& Agnieszka Kuczkiewicz-Fraś. 
the topics that Agyeya will develop in the three other texts presented in this paper: 1) the stranger, or non-indigenous visitor, who comes to the mountains in search of some "lost paradise", full of naiveté and preconceived ideas about the local population (as in "Seb aur dev"); 2) the wanderer who is in search of "liberation" in the immaculate beauty and peace of the Himalaya ("Bandom kā khudā..."); and 3) the devastating impact of concupiscent and violent men from the plains on the life of the women in the hills ("Hîlì-bon kī battakhem"). Therefore, this story will not be analysed separately from the rest, but comments will be made on it in relation with the other stories as appropriate.

In "Seb aur dev", the narrator demonstrates the influence of colonial and romantic discourse on the behaviour of the main character, an Indian professor of archaeology based in Delhi, named Gajanan Pandit. On holidays, the professor decides to go for a walk in the mountains in order to admire the beauty of the Kullu valley, with the secret hope of finding some hidden treasure in that still "pure" part of the country: ${ }^{11}$

Here too, in the charming Kullu valley, he has come thinking that he will find relics of the most ancient civilization of India and samples of the handicraft belonging to the Hindu era, and statues in iron or precious stones or clay, and who knows what else... ${ }^{12}$

This interest in relics and ancient statues of gods and goddesses is not unique to this story, as it finds an echo several decades later in the words of the famous traveller and Tibetologist Rahul Sankrityayan (1893-1963), who feels disappointed when, visiting the same Kullu valley, he finds only "recent and ugly statues" instead of the ancient art he was dreaming of (Sankrityayan 2009: 32).

11 The writer himself stayed there a couple of months in 1935 after his years of imprisonment in Delhi, and devoted two chapters to that valley in his travelogue Are yāyāvar rahegā yād?, first published in 1953 (Agyeya 2001).

12 Agyeya 1997: 376, my translation (यहां कुल्लू पहाड़ की सुरक्य उपत्यकाओं में भी वे यही सोचते हुए आये हैं कि यहां भारत की प्राचीनतम सभ्यता के अवशेष उन्हें मिलेंगे, और हिन्दू-काल की शिल्प-कला के नमूने।). 
In Agyeya's story, the professor's alternating feelings of wonder and disillusionment echo the various meetings and experiences marking each stage of his walk in the hills. Amidst an idyllic landscape, which the professor describes as Nature personified, he first comes across a "young hilly Rajput girl", whose "innocence makes her spontaneously start" when she sees this unexpected visitor (Agyeya 1997: 376). The beauty of the girl, compared in a poetic way to the beauty of the natural environment surrounding her, first arouses in his mind the image of a swan before giving place to the image of the goddess Sarasvati. ${ }^{13}$ The professor asks her where she lives, but instead of giving him an answer, "she look[s] at him with awe and start[s] hurriedly climbing the hill" (Agyeya 1997: 377).

The next two paragraphs epitomize the way foreigners and European-educated Indians perceived, or could perceive, the "pristine and innocent temperament of these local populations":

Smiling, the professor continued his path. He really liked the innocence of that girl. How plain, simple and straightforward are these people, he started thinking. Playing in the comforting embrace of Nature, they have no worry, no apprehension, no greed, and no covetousness. They spend their days eating and drinking, grazing their cattle, and singing and dancing. It was but normal to feel shy at the view of a man not belonging to the place. What could these good creatures, immersed in their own world, have to do with foreigners?

Moving ahead, the professor started thinking. If these good people were no more alive, how could the relics of the ancient civilization remain as they are now? God forbids! If these people had been educated in the European way, they would have killed each other, and not even ashes would have remained of them. ${ }^{14}$

13 The presence of a little cascade between the professor and the Rajput girl adds an erotic connotation to this passage. On the erotic connotation of "running water" in Indian literature, see Damsteegt 2001a, especially note 7.

$14 \mathrm{Ibid}$. (प्रोफेसर साहब मुस्करा कर आगे चल दिये। बालिका का भोलापन उन्हें अच्छा-अच्छा-सा लगा। सोचने लगे, कितने सीधे सादे सरल स्वभाव के होते हैं यहां के लोग ! प्रकृति की सुखद गोद में खेलते हुए इन्हें न फिक्र है, न खटका है, न लोभ लालच है। अपने खाते-पीते, ढोर चराते, गाते-नाचते दिन बिता देते हैं। तभी तो बाहर से आनेवाले आदमी को देखकर संकोच होता है। अपने-आप में लीन रहने 
In order to accentuate the negative effect European hegemony had on the subcontinent, the professor then thinks of the counter-example of Faxian and his epoch, when interfering with the people they were meeting was considered a major fault.

The main point in this first part of the story is the valorisation of the "naturally good" temperament of the hill populations, who are perceived as untouched by the negative effects of British education and dominion, unlike the situation in the Indian plains, where stealing and corruption of mind have become a rule. ${ }^{15}$ It must be noted here that this apparent naivety and ignorance of the real situation in the hills is related to the fictional character's view, representing a kind of elitist and European-educated city-dweller, and should not be misread

वाले इन भले प्राणियों को बाहरवालों से क्या सरोकार है ? आगे बढ़ते-बढ़ते प्रोफेसर साहब सोचने लगे, ऐसे भले लोग न होते, तो प्राचीन सभ्यता के जो अवशेष बचे हैं वे भी क्या रह जाते ? खुदा-न-खास्ता ये लोग यूरोपियन सभ्यता के सीखे हुए होते तो एक-दूसरे को नोच कर खा जाते, उसकी राख भी न बची रहने देते।). This description of the girl is thus imitating, but only imitating, the way the British, and later on the Indian reformists, viewed the behaviour of indigenous women in the hills. Snehi (2011: 77) uses Kipling's short story "Lispeth" to illustrate this rhetoric: "Kipling's works show how the nature and sexuality of the women of the hills become an object of the colonial gaze. He assigns typical characteristics to hill women, like 'her falling in love at the first sight', 'openness about her feelings', 'unmanageable', 'barbarous and indelicate', and 'unclean'. Reforms attempted to control such active desires and aggressive impulses of women. The reorganization of gender relations, especially conjugality and the strengthening of patriarchy, proved to be the most crucial elements in this enterprise."

15 The perception of the professor in this story echoes remarkably many old colonial representations of these populations. At the beginning of the nineteenth century, Captain Charles P. Kennedy, founder of Shimla hill station, wrote: "Where there is so little crime, it may be inferred that the morality of the inhabitants is the cause; certain it is that there is less falsehood and theft [among the Paharis of the Simla hills] than in any quarter of Asia" (quoted in Kennedy 1996: 63). Even if the story "Seb aur dev" is located in the Kullu valley and not in Shimla, the situation is described exactly along the same lines. 
as being the exact point of view of the author himself. Agyeya was all too well aware of the presence of the British administration and tourism in the Himalaya and of the impact on its population to be attributed such a perspective. ${ }^{16}$

The rosy picture is broken in the next part-in fact, the whole aim of the story is to subsequently unravel this naïve vision-, when the professor suddenly meets a boy stealing apples from trees. "It seemed to him that this boy was completely destroying, in one stroke, that noble and ancient civilization (prācin a aryă sabhyătā) that had been perpetuated intact for centuries, since the time of Faxian". ${ }^{17}$ This is not an insignificant event, as it is the meeting with this same boy at the end of the story that will make the professor realize that, by taking away from an abandoned temple the beautiful statue of a local goddess (for "purely" archaeological motives, he thinks), he is indeed committing an even more serious robbery:

It was as if the professor had suddenly been struck by lightning. A sentence of a blinding light had been etched for a second before his eyes: "He has only stolen an apple; you have plundered a sanctuary!"18

Thus, the narrator makes us understand that the professor's "purely" academic and archaeological interest is no different from a robbery, and that he too- like anybody with modern educationtakes an active part in the transformation of indigenous cultures. Although the narrator condemns this attitude; the way he focuses his attention on the professor without giving voice to the local inhabitants supports, somehow, this hegemonic position. None of the indigenous

16 The author precisely deals with this question in his Are yāyāvar rahegā yād? (Agyeya 2001: 100-102).

17 Agyeya 1997: 378 (उन्हें जान पड़ा कि यह लड़का उस सारी प्राचीन आर्य सभ्यता को एकसाथ ही नष्ट-भ्रष्ट किए दे रहा है जो फ़ाहियान के समय से सदियों पहले से अक्षूण्ण बनी चली आई है।).

18 Ibid.: 382 (एकाएक प्रोफ़ेसर साहब पर मानो गाज गिरी। एक चौंधिया देनेवाला आलोक क्षण-भर उनके आगे जलकर एक वाक्य लिख गया, "इसने तो सेब ही चुराया है, तुम देवस्थान लूट लाए !"). 
characters utter a word in the story, except for the priest (pujāri in Manali, who does not seem very interested in informing the professor about local temples and warns him, as it were, of spirits (bhīt) residing in the old ruined temple that contains the statue of the goddess (devi). Although the Hidimba temple - temple of the most important local goddess of the valley ${ }^{19}$ - is located in Manali, it is not this goddess that is meant here, as her temple is still active, unlike the temple of the story. These spirits belong, explains the pujāri , to the ancient "very glorious kings" of the place.

Reference is thus again made of the glorious past of the region, even if only spirits, stones and old statues remain from that period. The question might then be asked of whether there is, behind this stress on ancient times and the will to preserve the local cultures, a genuine interest on the part of the narrator in the specificities of their religious practices and beliefs. Actually, the story lacks information in this respect. Mention is made of the temple dedicated to the seer Manu, which owes its fame to its uniqueness in the world. It is linked to Hinduism in general and has nothing special to do with local peculiarities. The professor knows that there are hundreds of temples in the region and urges the pujāri to indicate him one of them. ${ }^{20}$ It is then that the temple of the goddess is named.

19 On the role played by Hidịmbā (or Haḍimbā) in the valley, see Luchesi 2006: 69-73; on the still current importance of local deities in everyday life in Kullu, see Berti 2009b.

20 It echoes a remark made by Agyeya in his travelogue Are yāyāvar rahegā yād? (Agyeya 2001: 88, my translation): "Kullu is the cradle of the primeval Hindu civilisation. Here, every town and village has its own god, who is worshipped by the people, installed in its own temple [...]. Because of the hundreds of gods and goddesses and of their temples, and because of this huge assembly of gods, the province of Kullu has been named 'devătāom $k \bar{a}$ añcal' (valley of the gods)." (कुलू प्राचीन हिंदू सभ्यता का गहवारा है। यहां प्रत्येक कस्बे और ग्राम के अपने-अपने देवता है, जो अपने-अपने मंदिरों में बैठ हुए ही लोगों की पूजा पाते हैं $[\ldots]$ सैकड़ों देवी-देवताओं और उन के मंदिरों के कारण, और इस 
Having reached the temple, the professor finds inside one black stone statue of the Devī, one brass statue of Ganeśa and one immaculate white sivling, the phallic symbol of the god Siva; nothing particular with regard to regional forms of religion. What sets the sequence a little bit apart from modern, mainstream Hinduism is the way the professor imagines the worship received by the statue:

For five hundred years it will have remained here. Who knows how many pūja she must have received, by how many fresh, warm and pure blood sacrificial baths her divine beauty must have been cleansed, and now, for how many years has she had to endure the disgusting tickling of the long nosy antennas of these crawling insects... Phew, what indifference to the divine! ${ }^{21}$

The professor is tempted to take this invaluable statue and bring it to a museum. He, however, hesitates to do so and feels some fear in that desolate and silent hilly landscape: "What am I afraid of? Of ghosts (pret)? Am I superstitious (andhaviśvāsì), like local people, to believe in ghosts?" (ibid.). The notion of "superstition" is thus attached to the local believers - a notion that is used in other stories too, as will be seen below-with a slight touch of self-irony from the professor.

To sum up, we can note that no information is given in this story about the actual practices and believes of the local inhabitants. If the narrator makes us understand that the romantic vision of the professor about the life and populations of the Himalaya is erroneous, nothing is, nevertheless, said that would supply a deeper and more accurate knowledge of the people of Kullu. In "Pahāṛi jīvan" too, despite the strong desire of the main character (Girish, a student

विराट देव-सम्मेलन के कारण ही, कुलू प्रदेश का नाम 'देवताओं का अंचल' (वैली आफ़ द गाड्स) पड़ा है।).

21 Agyeya 1997: 380 (पांच सौ वर्ष से यह यहीं पड़ी होगी; न जाने कितनी पूजा इस ने पाई होगी, कितनी बलियों के ताजे गर्म-पूत रक्त से स्नान करके अपना दैवी सौन्दर्य निखारा होगा, और अब कितने बरसों से इन रेंगते हुए कीडों की लम्बी-लम्बी जिजासु मूँछों की ग्लानिजनक गुदगुदाहट सह रही होगी... उफ़, देवत्व की कितनी उपेक्षा!). 
from Lahore) to know the reality of mountain life (in this case, in Dalhousie, in present-day Himachal Pradesh) and the few descriptions that are made of the local people (mainly at the bus station), the hill-dwellers are in the end only described in their relationship of subordination to the harsh and dominating people from the plains (ibid.: 224, 227). In this story, the conclusion is that life in the mountains remains unfathomable and inaccessible to the outsider, because "mountains say nothing, they have no tongue at all" (ibid.: 228).

The contrast between the beauty of the Himalayan valleys and the "corrupted" European way of life is again highlighted in the short story "Bandom kā khudā, khudā ke bande", which was written four years after "Seb aur dev" and follows a more or less similar plot. There, Anand, ${ }^{22}$ a citizen who wants to flee the noise and dirtiness of his town, goes walking in the hills around Chakrata, a cantonment town in the district of Dehradun, not far from Mussoorie (see Figure 1). Heading towards a belvedere where, according to the guidebook he has read, he will be able to admire the snowy peaks surrounding Badrinath, ${ }^{23}$ he thinks of the ugly houses he has seen on the way, bearing the inscription "For militaries only" and "For Europeans only". Saddened with this thought, he tries to remember that he is actually walking on the footpaths of "Chakrata, where blows the healthiest air throughout India, and where are found the nicest walks throughout India". ${ }^{24}$ But almost immediately, his path crosses that of two Europeans (gore) soldiers and, a few minutes later, two women "with red lips and too much makeup... exactly like the red tin roofs" (ibid.: 474) of the British bungalows they are coming from. All these unpleasant meetings

22 The name Anand (änand) is not without significance in this short story. It bears evident links with the philosophy either of the Advaita Vedānta or of Kashmir Shaivism, but also with Buddhism.

23 One of the four major Hindu places of pilgrimage in that part of the Himalaya.

24 Ibid.: 473 (चकरौते में ही, जहां की हवा भारत-भर की सबसे अधिक स्वास्थ्यकर हवा है जहां के रास्ते भारत भर के सर्वोत्तम सैर के रास्ते हैं). 
increase his hatred of foreigners and their propensity to appropriate for themselves the things and places where they settle, to depersonalize them, like when British cartographers renamed all the Himalayan summits, thus denigrating the ancestral names given by the Purānas (ibid.). His desire to flee their presence increases even further and pushes him to hasten towards the belvedere, the goal of his trip.

In this part, antagonistic by nature, Anand's mind is constantly balancing between his hatred for whatever represents European colonialism (army, prostitutes, expanding modern cities, ugliness) and his desire to find an authentic, peaceful place in order to immerse himself in the "blameless and blissful beauty of the Himalaya" (ibid.: 473). As has previously been stated, this topic is already found in the story "Pahāṛ̂i jīvan" (ibid:: 225). However, in the latter it is not linkedat least explicitly - to the European presence, but to the Indian situation and the distressing life of its towns in the plains.

In the next part, the vocabulary used-highly philosophical and Sanskritized - as well as the emphasis on the idea of liberation (mukti), strongly link the cultural background of the story to the philosophies of Advaita Vedānta and Kashmir Shaivism. ${ }^{25}$ If this part of the story is extremely interesting with regard to modern interpretations of "classical" forms of Hinduism, it says nevertheless nothing about the cultural and religious features of the populations living in the Himalaya. Like in "Seb aur dev", the specificities of the Himalayan customs and believes do not form the topic of the story.

In this case, the main message conveyed by the story is the idea that such idealistic vision of a pure, untouched land where liberation

25 In direct connection with the meaning attached to the name of the main character, Anand, but also with passages including some of the main concepts of these systems, like this one: मुक्ति के द्वार पर, जहां मानव ईधर को प्रतिबिम्बित करता है, जहां ईध्धर मानव की शक्ति का प्रक्षेपण हो जता है, जहां ईध्धर और मानव का साक्षात्कार होता है, जीवन के अन्तिम चरम एकान्त में-निभृत, आवाक्, रहस्यमय, साक्षात् संगम-किसी चीनी दार्शनिक ने कहा है, "जब मैं आनन्दित होता हूं तब मैं मौन होता हूं-" मौन ही आनन्द की चरमावस्था है, मौन ही परम सत्य है। मौन ही परम चिन्मतता है। (ibid.: 475, my emphasis). 
would be possible is but a dream, an illusion. ${ }^{26}$ There is no single space left in India that has remained preserved from the external world and its influences. Thus, in the third and last part (very short, just a few paragraphs), the whole dream attached to Anand's walk in the hills suddenly collapses when he sees, written on the bench at the belvedere, this insult: "Mother's... of the one who sits here" (is bemc par baithne vāle $k \bar{\imath} . .$.$) . In the end, even the mountain is "polluted"$ by an external, aggressive presence, and the heavenly peace Anand thought he would reach is destroyed by the insult written on the bench, a sign of the corrupted world he condemned but mistakenly thought to be able to abandon in the plains. ${ }^{27}$

Military presence in the hills and its violent behaviour towards the indigenous becomes the focus of the story "Hî̀ 1 i-bon kī battakhem", written the same year of the Independence and belonging to the group of stories linked to the author's years in the army (1943-1946), during which he was mainly posted on the Burma front. In the wake and as a result, as it were, of the two previous stories analysed above, the "naïve" representation of the indigenous woman, which was seen as pure and close to her feeling in "Seb aur dev", is used here with a more tragic conclusion. In this story, the same contrast is made between the sensitive and spontaneous local woman and the rational and self-possessed, but potentially dangerous, stranger. ${ }^{28}$ The narrator

${ }^{26}$ For a close analysis of this short story seen as a clear instance of anticolonial criticism in Hindi literature and questioning the topics of civilization and liberation, see Damsteegt 2001b.

27 Or, in Damsteegt's terms: "Anand has not been able to leave civilisation completely behind, has as though brought it with him", which, according to the scholar, "implies that freedom, finding God, is a matter of mentality rather than outward circumstances like cities or nature" (ibid.: 164).

${ }_{28}$ The same pattern is already present in "Pahāṛi jīvan", for instance in this emblematic passage: "Who knows why he suddenly thought of Karuna [i.e. compassion, tenderness], one of his childhood friends and distant relative cousin, who continuously longs for going to the mountains and keeps saying that mountain life must be so spontaneous, so pure, so self-evident-as if she 
speaks of Hili-Bon, a single woman from a Khasi "tribe" in present-day Meghalaya (then Assam, in a fictitious[?] village called Nang-thlam) as someone about whom "[o]ne could not be sure whether she was at all aware of" her surroundings (Agyeya 1962: 17, translation by Agyeya). What is more, a "more astute observer" (that is, someone rational like the narrator or any man foreign to these hills) would have noticed that "an invisible curtain had also been drawn across her mind, so that while her senses received all external stimuli of perception, the channels that conveyed these to the brain or roused reactions were sealed". ${ }^{29}$

Captain Dayal is a soldier of the Army Engineers, on leave for a few days, looking for some entertainment in the hills. During a walk, he comes upon Hili-Bon, whose geese ${ }^{30}$ are being slaughtered one by one every two or three days by a fox, something that "never happened in previous years" ( $i b i d$.). He willingly offers to chase and kill the murderer, in order to bring back security to her flock. But what the story soon implies in reality is that the behaviour of the fox is strongly linked to the behaviour of the soldiers, and strangers in general. What the fox has done to the helpless geese is a symbol of what alien men have done to the Khasi women:

was spontaneously singing some wordless prelude in ecstasy! He started thinking, is mountain life really like this, or is this only the dream-like desire of his sentimental cousin?" (उसे न जाने क्यों एकाएक अपनी एक बाल्य-सखी और दूर के रिश्ते की बहिन करुणा का ध्यान आया, जो सदा पहाड़ पर जाने के लिए तरसा करती है, जो कहती रहती है कि पहाड़ का जीवन कितना स्वच्छंद होगा, कितना निर्मल, कितना स्वतः सिद्ध-जैसे कि आनंदातिरेक से अनायास गाया हुआ शब्दहीन आलाप ! वह सोचने लगा कि क्या सचमुच पहाड़ी जीवन ऐसा ही होता है, या यह उसकी भावुक बहिन का इच्छा-स्वप्न है ?, Agyeya 1997: 217, my emphasis).

29 Ibid.: 17 (उसके मन पर भी कुछ शिथिल और तन्द्रामय छा गया है, जिससे उसकी इन्द्रियों की ग्रहण-शीलता तो ज्यों-की-त्यों रही है पर गृहीत छाप को मन तक पहुंचाने और मन को उद्वेलित करने की प्रणालियां रुद्ध हो गयी हैं..., Agyeya 1997: 536).

30 This is the English word used by Agyeya for "बत्तख" (battakh, in the Hindi text). It can also be a duck, as it is usually meant by the Hindi word बतख़ (batakh, in its standard form). 
How many strange faces had she encountered during the three of fours years of war, how many old types; faces of joy and laughter, hunger and madness, greed, cruelty and pride; faces twisted with lust and grubby with sin. She knew that the joys and sorrows, the fulfillments [sic] and frustrations, the sufferings and desires of scores of women in her village were linked with these passing faces; not merely linked but so tangled that the atmosphere had grown turgid with an alien pressure. ${ }^{31}$

In this story, like in the others, the main idea is that the indigenous populations and the "natural" beauty of the Himalaya - regularly linked to feminine figures and values - have been cut from their authentic and ancestral roots by men who came from "abroad". ${ }^{32}$ The result is that local people have lost the innate connection to their senses and act now in an alien, incomprehensible way, like when Hili-Bon starts chopping off the heads of all her own geese at the end of the story, a symbol of the inexorable death, or suicide, of her culture.

What is also conveyed by this story is a feeling of nostalgia, through Hili-Bon's memory, of a period, "many years ago", when the structure and life of her clan was natural and still preserved:

31 Agyeya 1962: 19-20 (युद्ध की अशान्ति के इन तीन-चार वर्षों में कितने ही अपरिचित चेहरे दीखे थे, अनोखे रूप; उल्लसित, उच्छवसित, लोलुप, गर्वित, यावक, पाप-संकुचित, दर्पस्फीत मुद्राएं... और वह जानती थी कि इन चेहरों और मुद्राहों के साथ उसके गांव की कई स्त्रियों के सुख-दुःख, तृत्ति और अशान्ति, वासना और वेदना, आकांक्षा और सन्ताप उलझ गये थे, यहां तक कि वहां के वातावरण में एक पराया और दूषित तनाव आ गया था।, Agyeya 1997: 539).

32 Although without this idea of uprootedness from ancestral origins, the story "Pahārị jīvan" too deals with male domination (symbolized here by a merchant, seț sāhab) over the women living in the mountains. Even more, the narrator of this story expands the critique to the whole of Indian society by making Girish say that "in a country where even men are slaves, it is better to die than be a woman", to which his sister replies: "Those who have seen things from above, they can experience inferiority; but we women have always remained oppressed (dalit)!" ("जिस देश में पुरुष भी गुलाम हों, उसमें स्त्री होने से मर जाना अच्छा है" [...] "निचाई का अनुभव वे कर सकते हैं, जिन्होंने कभी ऊपर उठ कर देखा हो; पर हम स्त्रियां तो सदा से ही दलित हैं !", Agyeya 1997: 223). 
Hili's father had been the Diwan of the tiny feudal state in which he lived. She was the eldest of the three daughters and the prettiest. In the matriarchal society of the Khasis, social power rested with the women; in Nang-thlam, Hili was a force to be reckoned with. In the Nong-Krem festival, when the men and women of all the tribal clans gathered to make sacrifice to the deified spirit of the mountain, their protector, Hili, by tacit consent, invariably led the dance. ${ }^{33}$

This is the only passage in Agyeya's short stories of this selection that provides a description of the rites and customs of the hill populations. In another (very short) paragraph Hili-Bon speaks of her clan's mythology: "We Khasis believe that earth and sky were once united but man cut the artery that joined them. Since then they have been separate and the wound of the earth does not heal." 34 This is her answer to the captain's attempt to sympathize with the Khasis' fate by saying, after the woman reminds him of army officers' "visits" to Khasi homes: "Plainsmen have always been hard on the people of the hills. It is like the inhabitants of a nether world ( $p \bar{a} t \bar{a} l v \bar{a} s \bar{\imath})$ trying to avenge themselves upon the gods." 35 This explicit comparison sounds a bit like an admission of guilt from the captain; nevertheless, the impression remains at the end that his general behaviour corresponds

33 Agyeya 1962: 19 (हीली के पिता उस छोटे-से माण्डलिक राज्य की दीवान रहे थे। हीली तीन सन्तानों में सबसे बड़ी थी, और अपनी दोनों बहिनों की अपेक्षा अधिक सुन्दर भी। खासियों का जाति-संगठन स्त्री-प्रधान हैं; सामाजिक सत्ता स्त्री के हाथ में है [और वह अनुशासन में चलती नहीं, अनुशासन को चलाती है।] हीली भी मानो नाइ्-थ्लेम की अधिष्ठात्री थी। 'नाङ् क्रेम' के नृत्योत्सव में, जब सभी मण्डलों के स्त्री-पुरुष खासिया जाति के अधिदेवता नगाधिपति को बलि देते थे और उसके मत्त्य प्रतिनिधि अपने 'सियेम' का अभिनन्दन करते थे, तब नृत्य-मण्डली में हीली ही मौन सर्वसम्मति से नेत्री हो जाती थी; Agyeya 1997: 538 (the author's English translation is significantly simplified).

34 Agyeya 1962: 20 ("हम लोग मानते हैं कि पृथ्वी और आकाश पहले एक थे-पर दोनों को जोड़ने वाली धमनी इन्सान ने काट दी। तबसे दोनों अलग हैं और पृथ्वी का घाव नहीं भरता।", Agyeya 1997: 540).

35 Agyeya 1962: 20 ("नीचे वालों ने हमेशा पहाड़ वालों के साथ अन्याय ही किया है। समझ लीजिए कि पातालवासी शैतान देवताओं से बदला लेना चाहते हैं !", Agyeya 1997: 540). 
to a paternalistic attitude, symbolic of the hegemony of the central power based in the plains, especially in Delhi, over the remote cultures of the mountains.

The focus is no more as strictly on the male character as it is in the two previous stories - it is now rather on the female character, although not limited to her. The narration could then give the impression that Agyeya has now changed the focus of his representation from the dominant masculine world to the "subaltern" position of the Khasi woman. That would be a kind of Copernican revolution in respect to the topic dealt with here. However, the contrast between, on the one hand, the seemingly lack of consciousness of Hili-Bon and her "mindless" behaviour, as repeatedly described by the narrator, and on the other hand the rationalist attitude of the captain, results in the fact that some ambiguity remains as to the way to interpret this story. Nevertheless, it corresponds with a strikingly recurrent pattern in the four stories taken into consideration, which can be summarized as follow:

spontaneity, beauty of Nature and freedom, which act as catalysts in the stories, are represented by women or female symbols (Karuna; the young hilly Rajput girl and the goddess; the Himalayan mountains; Hili-bon);

interrogation and will to discover the truth are represented by leading and/ or rational male city-dwellers (Girish; the professor; Anand; captain Dayal);

the disruptive element that brings an unexpected end to the story and goes against the male "hero's" quest — and thus, against the expected issue of the story-is represented by a disturbing and "immoral" element (the girl selling her body; the boy stealing apples; the dirty words on the bench; Hili-Bon's slaughter).

It can be concluded from these stories that whatever the mental representation of the mountain world by the main characters - who belong to the same socio-cultural background as the writer, and certainly a majority of his readers too- and their aim in going to the Himalaya, this representation finally results in a reversal of their situation because of an opposite and irrational force that breaks into the picture at the end and, thus, demonstrates to the reader the inadequacy of the initial worldview. 
What appears too, especially in the last story, is that the tension between the impact of the alien world on the Khasi population and the feeling of nostalgia for ancient times results in Hili-Bon's utter alienation:

How come she, queen of Nang-thlam, today in her thirty-fourth year, sat alone minding her pots of geraniums, alone in the village, alone in her house, utterly alone within herself? ${ }^{36}$

This feeling of alienation and the narrative focus on a female character and her solitude in the background of the Himalaya constitute two major topics of the short stories written after Independence, as will be clear in the following section.

\section{Second period: stories after 1947, by Verma, Rakesh, and Sobti}

The following three emblematic short stories of the decades following Independence have been retained for the second part of this literary analysis: "Parinde" ("Birds", written in 1955, published in 1959) by Nirmal Verma (1929-2005), "Mis pāl" ("Miss Pal", 1961) by Mohan Rakesh (1925-1972), and "Bādlom ke ghere" ("The Encircling Clouds", 1980) by Krishna Sobti (1925-). In these texts, the Himalayan background is mainly used as a symbolic place of utter solitude, imbued with the ideas of renunciation, estrangement and melancholy, even if the places of "action" are named according to existing locations: Ranikhet in "Parinde", Raison (Kullu Valley) in "Mis pāl", and Nainital and Bhowali in "Bādlom ke ghere". Illness is also pervasive, such as in "Parinde" and "Bādlom ke ghere", or physical troubles - at least the way others look at it - when illness is not present as such, like in the case of Miss Pal's obesity. The events - or rather the dialogues, as these stories generally lack action - are set in an environment that

36 Agyeya 1962: 19, my emphasis (यह कैसे हुआ कि वह 'नाइ् क्रेम' की रानी, आज अपने चौंतीसवें वर्ष में इस कुटी के जरेनियम के गमले संवारती बैठी है, और अपने जीवन में ही नहीं, अपने सारे गांव में अकेली है ?, Agyeya 1997: 539; literally, the Hindi version says "alone not only in her life, but too in the whole village"). 
is mainly cold and dark. Unlike in Agyeya's stories, where the beauty of the mountains is highlighted, it is here essentially an unsettled weather that is described, while clouds, wind and rain echo the transient and unsteady feelings and emotions of the characters, or their illness, in contrast to the presumed steadiness of the Himalayan environment. Everything looks fragile, vain and evanescent, like in the very first and last lines of Sobti's short story:

Lying in the small cottage at Bhowali Sanatorium, I look at the hills stretching away in front of me. I look at the encircling clouds, swollen with rain, and at the barren ones, wisp-like and shrivelled. I look at the mist groping in vain, and at my own body, bare as a tree that has shed its leaves. [...]

Lying down in front of the window and flustered by my loneliness, when I look out I see that face with her curly hair in the foggy encircling clouds, that...

Looking at the constantly changing colours of the medicine bottles, at least I have realized that my soul (man) will not wander for long in this ending body. One day, just while looking out of the window, I will merge into these clouds... into these encircling clouds... ${ }^{37}$

\section{Or in Nirmal Verma's "Parinde":}

Rains in the hills are unpredictable. A short while ago smoky clouds were thundering, the whole town was shivering and wet-now the sun-washed blue sky was emerging from behind the fog and spreading. [...]

In the smoky sky was a flock of birds flying towards them in a triangular formation from behind the mountain range. Latika and the Doctor watched the birds. Latika remembered that every year, just before the winter vacation, these birds flew towards the plains, breaking journey for some days at these hill stations, waiting for the snow, then flying downwards to strange, unknown lands...

37 Sobti 1996: 209, 227-228, my translation (भुवाली का इस छोटी-सी कॉटेज में लेटा-लेटा मैं सामने के पहाड देखता हूँ। पानी-भरे, सूखे-सूखे बादलों के घेरे देखता हूँ। बिना आँखों के झटक-झटक जाती धुन्ध के निष्फल प्रयास देखता हूँ और फिर लेटे-लेटे अपने तन का पतझार देखता हूँ। [...] खिडकी के सामने लेटे-लेटे, अकेलेपन से घबराकर जब मैं बाहर देखता हूँ, तो धुंधभरे बादलों के घेरों में घुँघराले बालोंवाला वही चेहरा दीखता है, वही... आये दिन दवा के नये बदलते हुए रंग देखकर अब इतना तो जान गया हूँ कि इस छूटते-छूटते तन में मन को बहुत देर भटकना नहीं है। एक दिन खिडकी से बाहर देखते-ही-देखते इन्हीं बादलों में समा जाऊँगा... इन्हीं घेरों में...). 
Were they also waiting for something — she, Dr Mukherji, Mr Hubert? But waiting for what destination? Where would they go ${ }^{38}$

This impression of helplessness and disorientation is also present in Mohan Rakesh's "Mis pāl", even if the weather seems at first rather nice, before it changes for the worse:

It was a day or two before the full moon and the sky on three sides of us was pervaded by bright moonlight. The sound of the Beas was echoing in the air. Along with the rustling of the trees, a very slight rustling in the grass of the field made itself felt. The air was fresh and from behind the mountain before us a rising cloud was slowly, slowly gliding toward the moon.

"What's the matter, Miss Pal? Why are you so sad?" I asked. "If the rice got a little burnt, that's hardly worth getting upset about!"

She kept staring ahead at the misty outline of the mountain as though searching for something.

"I think, Ranjit, that my life has no meaning at all," she said. ${ }^{39}$

38 Verma 1996: 278, 291-292 (English translation by Jai Ratan, close to the Hindi version: पहाडों की बारिश का क्या भरोसा ? कुछ देर पहले धुआँधार बादल गरज रहे थे, सारा शहर पानी में भीगा ठिठुर रहा था-अब धूप में नहाता नीला आकाश धुन्ध की ओट से बाहर निकलता हुआ फैल रहा था। [...] पक्षियों का एक बेड़ा धूमिल आकाश में त्रिकोण बनाता हुआ पहाड़ों के पीछे से उनकी ओर आ रहा था। लतिका और डॉक्टर सिर उठाकर इन पक्षियों को देखते रहे। लतिका को याद आया, हर साल सर्दी की छुट्टियों से पहले ये परिन्दे मैदानों की ओर उड़ते हैं, कुछ दिनों के लिए बीच के इस पहाड़ी स्टेशन पर बसेरा करते हैं, प्रतीक्षा करते हैं बर्फ़ के दिनों की, जब वे नीचे अजनबी, अनजाने देशों में उड़ जाएँगे... क्या वे सब भी प्रतीक्षा कर रहे हैं ? वह, डॉक्टर मुकर्जी, मि. ह्यूबर्ट-लेकिन कहाँ के लिए, हम कहाँ जाएँगे ?, Verma 2005: 24, 37).

39 Rakesh 1979: 112 (English translation by Frances W. Prichett, close to the Hindi version: बारहीं या तेरहीं की रात होने से आकाश में तीन तरफ खुली चांदनी फैली थी। ब्यास की आवाज़ वातावरण में एक गूज पैदा कर रही थी। वृक्षों की सरसराहट के अतिरिक्त मैदान की घास से भी एक धीमी-सी सरसराहट निकलती प्रतीत होती थी। हवा तेज थी और सामने पहाड़ के पीछे से उठता हुआ बादल धीरे-धीरे चांद की तरफ सरक रहा था। "क्या बात है मिस पाल, तुम इस तरह गुम-सुम क्यों हो रही हो?" मैंने कहा, "चावल थोड़े खराब हो गए, तो इसमें इस तरह उदास होने की क्या बात है !" मिस पाल सामने 
Although in each one of these three texts the whole story is set in the Himalaya, their inhabitants and their culture never constitute the focus of the story. It is essentially the unease, the doubts and the melancholy of the main characters that are talked about at length. These are all visitors, foreigners or citizens from the plains who have settled there either because of their work or to cure some illness, and none of them belongs by birth or by family bounds to the places mentioned in the stories. Even after years of living there, they still do not feel at home, like for Latika and Dr Mukherji in "Parinde" (Verma 1996: 263, 275-76, 285), or are looked at by local people as outsiders, or even freaks (kamāl) in Miss Pal's case (Rakesh 1979: 117).

Except for the mention of the local apple orchards (which have make these valleys famous throughout the subcontinent and constitute an unavoidable topic for every writer travelling in that part of the Himalaya ${ }^{40}$, despite the fact that their presence is also due to British import), nothing is said about the distinctive characteristics of the place and of its indigenous inhabitants. We learn nothing about the personality of the mountain peoples (they are only mentioned in connection with their function), and when something is said about them, it is through the lens of gossips and conventional remarks. ${ }^{41}$ The same is true in regard to their specific customs and beliefs. Thus, the only situation where something is told about the local people is linked to the repetitive comments made by Miss Pal on their "superstitions" (andhaviśvās):

Miss Pal got up. Her breath was coming a little fast, and as we walked, she began to tell me how very superstitious the local people were. [...]

पहाड़ की धुंधली रेखा को देखती रही, जैसे उसमें कोई चीज़ खोज रही हो। "मैं सोचती हूं रणजीत कि मेरे जीने का कोई भी अर्थ नहीं है," उसने कहा।, Rakesh 2004: 22).

40 Like, obviously, in Agyeya's "Seb aur dev", but also, for instance, in Himācal by Rahul Sankrityayan (2009: 32).

41 "Karimuddin was a servant in the hotel. Stories of his laziness and shirking had been circulating among generations of students" (Verma 1996: 262-263). Or “"Man-eater of Kumaon!' Girish teased her” (ibid.: 277), and "She was wearing a full sleeved, cream coloured woolen jacket. Her neck was round like the Kumaoni girls" (ibid.: 280). 
They're illiterate people. I didn't even contradict them. They can hardly abandon their superstition in a day! No telling how many years it'll take! $[\ldots]$

After a cup of tea we'll go for a walk on the road uphill. There's a very old temple up there and the priest will tell you such stories that you'll be quite astonished. One day he was telling me that there are temples around here where people used to pray to the god for rain. Afterwards, if the god didn't send rain, they took him to the Hidamba Temple and hung him with a rope! Isn't that a delightful idea? If some god won't work for you, then hang him! I tell you, Ranjit, among the local people there's so much superstitionso much superstition that it can't be described. These people still live just as in the time of the Kauravas and the Pandavas; they have no links with the modern age. ${ }^{42}$

In this passage, although mention is made of the goddess Hiḍimbā-a very important goddess for Kullu (see note 19)-local people are, nevertheless, denigrated by Miss Pal for their "superstitious" practices and beliefs. Moreover, they are primarily linked to mainstream "Hinduism" via the "classical" Epic of the Mahäbhärata and not to some regional narrative. ${ }^{43}$ But more important than this opposition

42 Rakesh 1979: 110-111 (मिस पाल उठ खड़ी हुई। उसकी सांस कुछ-कुछ फूल रही थी। वह चलती हुई मुझे बताने लगी कि वहां के लोगों में कितनी तरह के अन्ध-विध्धास हैं। [...] "ये अनपढ़ लोग हैं। मैंने इनकी बातों का विरोध भी नहीं किया। ये लोग अपने अन्धविध्धास एक दिन में थोड़े ही छोड़ सकते हैं ! इस चीज में जाने अभी कितने बरस लगेंगे !" [...] "चाय की प्याली पीकर हम लोग ऊपर की तरफ घूमने चलते हैं। ऊपर एक बहुत पुराना मन्दिर है। वहां का पुजारी तुम्हें ऐसे-ऐसे किस्से सुनाएगा कि तुम सुनकर हैरान रह जाओगे। एक दिन वह बता रहा था कि यहां कुछ मन्दिर ऐसे हैं, जहाँ लोग पहले तो देवता से वर्षा के लिए प्रार्थना करते हैं, मगर बाद में अगर देवता वर्षा नहीं देता तो उसे हिडिम्बा के मन्दिर में ले जाकर रस्सी से लटका देते हैं। है नहीं मजेदार बात ? जो देवता तुम्हारा काम न करे, उसे फांसी लगा दो। मैं कहती हूं रणजीत, यहां लोगों में इतने अन्धविध्यास हैं, इतने अन्धविध्धास हैं कि क्या कहा जाए ! ये लोग अभी तक जैसे कौरवों-पाण्डवों के ज़माने में ही जीते हैं, आज के जमाने से इनका कोई सम्बन्ध ही नहीं है।", Rakesh 2004: 19, 20).

43 On the lasting and debated question of the relationship between "classical" Brahmanism and local cults of the Himalaya, and the influence of the former on the latters, see Zoller 2001. In Hindi literature too, this question has given rise to personal interpretations. For instance, in Are yāy $\bar{a} v a r$ 
between indigenous cult and Brahmanic tradition is the dichotomy made between the ancient time of the Epics (with their postulated superstitions) and "the modern age", which shall be the benchmark for today's society.

The characters are, however, not without inner contradictions, as Miss Pal's attitude toward life suggests: on the one hand, she denigrates these "superstitions", but on the other hand she believes that her difficult fate is the result of her vanity in her previous life - she was then a beautiful girl, very skilled in the arts, but did not show respect to her husband - and corresponds to the prediction made to her when she had her horoscope read by the Bhrgu-Samhitä, a Vedic treatise of astrology. This contradictory conception in Miss Pal's mindset, between her belief in this astrological prediction and her rejection of indigenous beliefs in favour of modern values gives rise to a tension - deprived of any suggested solution - that is illustrated not only by the narrator's surprise but also by the silence and "deep darkness" that begin to envelop the two characters. ${ }^{44}$

rahegā yād?, Agyeya (2001: 88-89) explains that "the form of Aryan religion (āryă-dharm) that is known as Hinduism (hindūdharm) has established itself here [i.e. in Kullu area] as a conqueror", and that the highly-celebrated Dusserah festival celebrating Rāma's victory over the demon king Rāvana, with Rāma being accompanied and surrounded by local divinities, can be seen as the symbolic result of the victory of the outsider mainstream "Hinduism" over the "countless local gods and goddesses, rșis and sages worshipped by the original residents."

44 "I continued to look at her in silence. Earlier in the day she had mentioned the local people's superstitions and made jokes about them. Suddenly, in the midst of talking, she too fell silent and her eyes became fixed on my face. It seemed as though something was trembling between her brightly painted lips. For a time we sat in silence. The cloud had spread over the moon and deep darkness enveloped us. Suddenly the lights in the next cottage were extinguished as well, so that the darkness began to seem even blacker and deeper", Rakesh 1979: 113 ("मैं चुपचाप उसे देखता रहा। अभी दिन में ही वह वहां के लोगों के अन्धविध्यासों की चर्चा करती हुई उनका मज़ाक उड़ा रही थी। सहसा मिस पाल भी बोलते-बोलते चुप कर गई और उसकी आंखें मेरे चेहरे पर स्थिर हो गईं। उसके लिपस्टिक से रंगे हुए ओठों की तह में जैसे उस समय कोई चीज़ कांप रही थी। 
Criticism of, or at least scepticism about, traditional religiosity is also present in "Parinde". Characters such as Ms Hood and Father Elmond are depicted as people stuck with out-dated and conservative moral values. Against this mindset, the main characters of "Mis pāl" and "Parinde" (religious feelings and practices are non existent in "Bādlom ke ghere") react by refusing conventional norms imposed by society, although they are not always completely free from them, like in Miss Pal's case.

Ultimately, nothing is said, however, about the specificity of the local culture. When, besides the recurrent descriptions of the mountains and the changing climate (to emphasize the mental turmoil of the characters and their unease in life and mutual relationships ${ }^{45}$ ), mention of cultural and human aspects is made in the texts, it is almost exclusively in reference to foreign elements, for instance European women rowing in boats on the lake at Nainital and British-like daily living ("Bādlom ke ghere"), or English tourists coming to Ranikhet for winter sports ("Parinde"), or the western-kind of breakfast and western songs playing on the radio ("Mis pāl"). But here, unlike in Agyeya's stories, the external presence does not lead to an argumentation on the dichotomy of hill versus plain, or indigenous versus foreign tension. The absence of interaction with local people is also a way to stress the fact that the characters from the outside have not chosen to come to the mountains from sheer interest in the local way of life or the pristine beauty of the mountains, but have rather (especially Miss Pal and Latika) tried to escape the "vicious" atmosphere (in its ecological as well as socio-psychological meanings) of the plain and overcrowded cities like Delhi. In this regard, gossip and denigrating

काफी देर हम लोग चुप बैठे रहे। बादल ने चांद को छा लिया था और चारों तरफ गहरा अंधेरा हो रहा था। सहसा साथ के कॉटेज की बत्ती भी बुझ गई, जिससे अंधेरा और भी गहरा लगने लगा।", Rakesh 2004: 23).

45 Unease in erotic relationships too, especially in Mohan Rakesh's story (see, for instance, quotations in notes 39 and 44 above), if one takes into consideration the fact that descriptions of the environment and especially of the moon and water are important connotations of the erotics in South Asian literature; on this topic, see Damsteegt 2001a. 
comments are attached to the "opponents" of the main characters, to those who symbolize reactionary and conservative voices, like Miss Wood and Father Elmond in "Parinde" (Verma 1996: 279), or the coworkers of Miss Pal before she leaves her job.

This, however, seems to go against the grain of these naì kahāni authors, who stressed the importance of feeling and realistically depicting life situations in their narratives, as it is emphasized in this interview Mohan Rakesh gave with K. P. Singh and Asghar Wajahat:

The sort of attachment that the writer had, or this sort of "pain" or "sorrow" he felt for the things around him, or the sort of disillusionment that was in his mind because of the life situation around him - these subjective reactions to the life situation were crystalized into an objective view of it. That's why you'll find that the naì kahāni is primarily an intimate story. It would distinguish it from Agyeya's short stories too. Take a story like Jayadol, for example. Well, by itself it might be a good story, but it doesn't show the writer's intimate interest in or knowledge of the life situation around $\mathrm{him}$. The story, then, is an idea, and there is some imagination and probably some moment in it which the author experienced. But the nā kahān $\bar{\imath}$ writer was also interested in the totality of time and the total emerging life situation around him. (Rakesh, Singh \& Wajahat 1973: 17, my emphasis)

Despite Rakesh's affirmation about the importance of the "objective view" of the life situation, one cannot but notice that nothing concrete is provided to the reader on the objective situation of the populations living in the Himalaya. On the contrary, characters seem to live in a kind of bubble zone where interactions only occur among peers, men and women belonging to the same socio-cultural milieu. In the end, we learn nothing more about their specific lives than what can be grasped from Agyeya's stories.

This answers the second question raised at the end of the introductory part of the present contribution. In both periods, the focus is on the characters that are visitors or newcomers in the Himalaya, and thus, somehow, the alter egos of the writers. Regarding the first question, that is the trope of Himalayan populations as inheritors of an ancient and authentic Hindu civilization, if it is only partly present in Agyeya's stories, it is no more present in the stories 
of the second group. This was apparently no more of an issue for their authors.

As for the last question, on the ways the narrators depict and "stage" the contact between the Himalayan populations and the outsiders, in these post-Independence texts, as in Agyeya's stories, the two worlds seem to live side by side. However, whereas in the latter, emphasis was put on the destructive impact of the external world on the hill populations, supported by numerous considerations on this issue by the narrators, in the former, the conflictual relation seems rather to have been internalized, in the form of a sense of alienation the characters feel in this mountain environment. The same contrast is true for the question of national identity, which is no longer an issue for the "new" generation of writers, contrary to the authors of the previous generation, like Agyeya, and to the politicians, addressing this question whether with a secularist approach or a Hindu nationalist agenda.

\section{Conclusion: continuity and changes in the topos of renunciation and liberation}

Beyond the differences between the stories, the Himalayan setting appears to be primarily used as a narrative device to explore and contest the relationship between the mountain world and the intrusive presence of the external world. Another topic, however, emerges from the analysis made in these pages. On the symbolic level, in all the stories considered in this paper, the Himalayan setting carries, to a greater or lesser extent, the meanings of renunciation and liberationwhether the character's quest is fulfilled or not is another question. The way this topic is dealt with differs, however, between one group of stories and the other. In Agyeya's stories, especially in "Bandom kā khudā..." and "Pahāṛ̂̄ jīvan", the idea of the everlasting purity and steadiness of the Indian mountains turns out to be but a chimera, and liberation through a wandering quest in the heights of the Himalaya remains an illusion. In Nirmal Verma's story too, the topic of liberation is strongly present, although the narrator does not explicitly state it. The celebrated Hindi critic Namvar Singh pointed it out very early, just 
one year after the publication of Parinde, in his article "Naȳ̄ kahān̄̄ kī pahlī krı̀i: Parinde" ("First Composition of Naȳ̄ Kahānī: Parinde"): "From a certain point of view, the problem of Latika in 'Parinde' is a problem of independence (svatantrătā) or liberation (mukti)!" 46 It can also be said, in the words of De Bruijn (2007: 15), that the "hill regions $[\ldots]$ form the backdrop for the search for identity and transcendental permanence against the fleeting an[d] socially restricted life in the city". We can, however, add that this "search" remains a search, and does not, at least in "Parinde", result in "steadiness"; it rather expresses constant doubts and moves between two worlds that as in Latika's mind, as in the following sentence:

Latika feels that what she remembers she wants to forget too, but when she really begins to forget, she gets afraid lest something of hers [is] taken away from her, something [is] lost forever. ${ }^{47}$

If renunciation might well be sought-after here, it is yet a feeling of failure, or indeterminacy at least, that predominates in the end.

Renunciation seems more actual — although in a negative wayin "Mis pāll" and "Bādlom ke ghere", as Miss Pal looks completely disconnected to the ordinary world that surrounds her, while Ranjit, the narrator of Sobti's short story, retires to his cottage at Bhowali Sanatorium, only to wait for his life to end - he is dying of a contagious disease. In both cases, Miss Pal and Ranjit are dead to the society; emptiness is what remains to them. These are the last lines of the two stories:

As the bus pulled away, she began to wave. She had both empty tins in her hand.

I waved back to her once; and until the bus turned, I kept seeing the empty tins waving in her hand. ${ }^{48}$

46 Singh 2008: 226 (एक तरफ से देखा जाय तो 'परिन्दे' की लतिका की समस्या स्वतंत्रता या मुक्ति की समस्या है !).

47 Verma 1996: 288-289 (लतिका को लगा कि जो वह याद करती है, वही भूलना भी चाहती है, लेकिन जब सचमुच भूलने लगती है, तब उसे भय लगता है कि जैसे कोई उसकी किसी चीज़ को उसके हाथो से छीने लिये जा रहा है, ऐसा कुछ जो सदा के लिए खो जाएगा।, Verma 2005: 34).

48 Rakesh 1979: 118 (बस चली तो मिस पाल हाथ हिलाने लगी। दोनों खाली डिब्बे वह अपने हाथों में लिए हुए थी। मैंने भी एक बार उसकी तरफ हाथ हिलाया और 
Looking at the constantly changing colours of the medicine bottles, at least I have realized that my soul (man) will not wander for long in this leaving body. One day, just while looking out of the window, I will merge into these clouds... into these encircling clouds... ${ }^{49}$

More generally, it can be stated at the end of this contribution that in experimental and modernist Hindi literature, the Himalaya remains a highly symbolic place for the topic of renunciation, respecting thus a topos of religious literature. If its traditional representation (an ascetic man pursuing a spiritual quest) is no longer valued in fictional works of this literature, its general idea of disconnection from the ties and norms of the society because of deep dissatisfaction with its values still provides the primary impulse towards a new way of life for the characters. While religious and philosophical aspects are still present in Agyeya's stories (especially in "Bandom kā khudā..."), they disappear in the short stories of the postcolonial period. Although renunciation remains important to the latter, what predominates, then, is the lack of explicit references to the commonly religious conception of renunciation: women and not men are primarily concerned by this quest, and neither community of ascetics nor remote locations are associated to them. Moreover, renunciation becomes more a negative way of liberating oneself from the everyday social bounds than a means towards absolute and valued liberation.

Before concluding this paper, I would like to come back to its title and especially to a topic that runs through all the stories presented in this article: wandering. Wandering is an appropriate metaphor for the "journey" these characters are experiencing, as all the stories develop the idea of exploration and discovery through wandering. A major difference appears, however, between the short stories belonging to the first group and those belonging to the second one. In the former, wandering takes the form of a concrete walk in the mountains and symbolizes the attempt by the character to get rid of the colonial presence

बस के मुड़ने तक हिलते हुए खाली डिब्बों को ही देखता रहा।, Rakesh 2004: 27).

49 Sobti 1996: 228 (see note 37 above for the Hindi version). 
and its influence on the mind of every educated citizen; in the latter, it becomes internalized, and symbolizes the character's quest for a deeper identity and meaning of life.

For sure, these and other new characters are bound to pursue their wandering before achieving their goal. This will certainly imply, fortunately, new stories and new wanderings in the Himalaya.

\section{Bibliography:}

Agyeya. 1962. Jaya-Dol (Collection of Stories). $3^{\text {rd }}$ ed. Kashi: Bharatiya Jnanpith.

Agyeya. 1997. Agyeya kī sampūrṇ kahāniyāmi. Delhi: Rajpal and Sons.

Agyeya. 2001. Are yāyāvar rahegā yād? [1953]. $6^{\text {th }}$ ed. New Delhi: National Publishing House.

Berti, D. 2009a. Passé, localité et nationalismes dans la région de Kullu (Inde du Nord). In: G. Krauskopff (ed.). Les Faiseurs d'histoires: politique de l'origine et écrits sur le passé. Nanterre: Société d'Ethnologie: 113-142.

Berti, D. 2009b. Kings, Gods, and Political Leaders in Kullu (Himachal Pradesh). In: M. Lecomte-Tilouine (ed.). Bards and Mediums in the Khas Kingdoms. Almora/Delhi: Himalayan Book Depot: 107-136.

Brass, P. R. 1990. The Politics of India since Independence. The New Cambridge History of India. 4, 1 The evolution of Contemporary South Asia. Cambridge-New York [etc.]: Cambridge University Press.

Chandra, N. 2007. The Pedagogic Imperative of Travel Writing in the Hindi World: Children's Periodicals (1920-1950). In: South Asia: Journal of South Asian Studies 30.2: 293-325.

Damsteegt, T. 2001a. The Erotics of Moonlight and other Connotations in Modern Hindi Literature. In: Modern Asian Studies 35.3: 727-71.

Damsteegt, T. 2001b. Ajñeya and Anticolonialism. In: D. W. Lönne (ed.).Tohfa-e-Dil, Festschrift Helmut Nespital. Reinbek: Dr. Inge Wezler: 153-166.

De Bruijn, T. 2007. Reading Modernism in Hindi Writing: The Case of Naȳ Kahānī. Unpublished paper. 
Gandhi, M. K. 1997. Hind Swaraj and Other Writings [1909]. Edited by Anthony J. Parel. Cambridge: Cambridge University Press.

Kennedy, D. K. 1996. The Magic Mountains: Hill Stations and the British Raj. Berkeley-Los Angeles-London: University of California Press.

Luchesi, B. 2006. Fighting Enemies and Protecting Territory: Deities as Local Rulers in Kullu, Himachal Pradesh. In: European Bulletin of Himalayan Research 29-30: 62-81.

Pennington, B. K. 2005. Was Hinduism Invented? Britons, Indians, and the Colonial Construction of Religion. New York: Oxford University Press.

Rakesh, M. 1979. Miss Pal. Translated by Frances W. Prichett. In: Journal of South Asian Literature 14.3/4: 99-118.

Rakesh, M. 2004. Mis pāl [1961]. In: Mohan rākeś kī sampūrṇ kahāniyāìm. Delhi: Rajpal \& Sons: 9-27.

Rakesh, M., K. P. Singh and A. Wajahat. 1973. Interview with Mohan Rakesh. In: Journal of South Asian Literature 9.2/3: 15-45.

Sankrityayan, R. 2009. Himācal: ek sāmiskrtik yātrā. Vol. 2. New Delhi: Vani Prakashan.

Singh, N. 2008. Nayī kahānī kī pahlī kròti: Parinde [1960]. In: N. K. Nawal (ed.). Nāmvar sañcayitā. New Delhi-Patna: Rajkamal Prakashan: 225-236.

Snehi, Y. 2011. Diversity as Counter-Hegemony: Reet and Gender Relations in Himachal Pradesh. In: C. Singh (ed.). Recognizing Diversity: Society and Culture in the Himalaya. New Delhi: Oxford University Press: 75-97.

Sobti, K. 1996. Bādlom ke ghere [1980]. In: B. Sahni (ed.). Hind̄̄ kahānī sangrah. New Delhi: Sahitya Akademi: 209-228.

Teltscher, K. 2002. India/Calcutta: City of Palaces and Dreadful Night. In: P. Hulme and T. Youngs (eds). The Cambridge Companion to Travel Writing. Cambridge: Cambridge University Press, 191-206.

Verma, N. 1996. Birds. Translated by J. Ratan. In: B. Sahni (ed.). Anthology of Hindi Short Stories. New Delhi: Sahitya Akademi: 262-296. 
Verma, N. 2005. Parinde [1955]. In: Gyārah lambī kahāniyāmi. New Delhi: Bharatiya Jnanpith: 9-42.

Zoller, C. P. 2001. On the Relationship between Folk and Classical Traditions in South Asia. In: European Bulletin of Himalayan Research 20.1: 77-104. 